\title{
Knowledge, Attitude and Practices about Blood Donation among Undergraduate Medical Students in Karachi
}

\author{
Zeeshan Ahmed ${ }^{1 *}$, Mubashir Zafar ${ }^{1}$, Adeel Ahmed Khan², Muhammad Umair Anjum ${ }^{3}$ and Muhammad Asad Siddique \\ ${ }^{1}$ Department of Community Medicine, Dow University of Health Sciences, Karachi, Pakistan \\ ${ }^{2}$ Department of Community Health Sciences, Aga Khan University, Karachi, Pakistan \\ ${ }^{3}$ Royal Alexandra Hospital, Paisley, Scotland \\ ${ }^{4}$ School of Health Sciences, Queen Margaret University, Edinburgh, UK
}

\section{Abstract}

Background: Blood donation is a major concern to the society as donated blood is lifesaving for individuals who need it. In Pakistan, the concept of voluntary blood donors is almost non-existent due to the absence of blood donor motivation and retention strategies. The healthy, active and receptive huge student population can be potential blood donor to meet the safe blood requirements. The objective of this study was to determine the knowledge, attitude and practices about blood donation among undergraduate medical students in Karachi.

Methods: A cross sectional study was conducted in two public and one private medical college in Karachi from January to March 2012. A total of 600 medical students were interviewed with the help of structured questionnaire. Data analysis was performed in SPSS version 19. Multiple regressions were used to examine the effect of different independent variables on a single dependent variable to test the statistical significance at $95 \%$ confidence level.

Results: The majority of participants (92\%) had appropriate knowledge regarding the various aspects of blood donation. Attitude domain showed that around $42 \%$ of students were positive about blood donation. Around $50 \%$ of students showed willingness to donate blood. After adjusting for potential confounders, male gender was associated with appropriate knowledge, positive attitude and willingness for blood donation when compared against female gender.

Conclusion: Good knowledge about blood donation practices is not transforming in donating blood. Interactive awareness sessions on blood donation should be organized during undergraduate years and opportunities for blood donation should be created for the students, which can greatly enhance the movement for "voluntary non-remunerated blood donation", to ensure good quality of blood and safe modern medical care.

Keywords: Blood donation; Medical students; Knowledge; Attitude; Practices

\section{Introduction}

Every second for every day, people around the world of all ages need blood transfusions to survive. Millions of blood units were collected from donors every year but demands are increasing day by day that is pushing for sufficient and timely provision of blood [1]. Blood has always held secretive charm for all and is considered to be the living force of our body. In modern era, blood has been used since 1930 for various purposes [2]. After the introduction of blood banks it becomes more widely used in patients. In Pakistan more than 1.5 million pints of blood are collected each year. Among them about $65 \%$ is from replacement donors, $25 \%$ from volunteer donors and about $10 \%$ from professional donors [3]. Today, the use of whole blood is a well-accepted and commonly employed measure without which many modern surgical procedures could not be carried out [4].

The average donation rate in developed countries is 38.1 donations/1000 population (range 4.92-68.01) and in developing countries average 2.3 (range $0.40-7.46$ ) donations per 1000 population. The average number of blood donations per 1,000 populations is 12 times higher in high income countries than in low-income countries. An overwhelming 99 per cent of the 500,000 women who die each year during pregnancy and childbirth live in developing countries, with hemorrhage which invariably requires blood transfusion, the most common cause of maternal deaths [5].

The healthy, active and receptive huge student populations are potential blood donors to meet safe blood requirements. There is a paucity of studies on awareness, attitude and practices among medical students on voluntary blood donation. College students, particularly from medical colleges, can be a very good source of quality blood if they are motivated and are willing to be voluntary blood donors. Therefore, the objective of this study was to determine the knowledge, attitude and practices about blood donation among undergraduate medical students in Karachi.

\section{Materials and Methods}

\section{Study design, setting and study population}

This was a cross sectional study conducted in three medical colleges of Karachi during the period of January to March 2012. Students included from those medical colleges where atleast one blood bank adjacent to these medical colleges was present and provided informed consent.

\section{Sampling technique and sample size}

Purposive sampling was done to select the medical colleges. Two medical colleges were from public sector while one from private sector. Sample size was calculated from WHO software for sample size determination in health studies. Using proportion of prevalence of appropriate knowledge $42 \%$ [6], bound on the error (B) $4 \%$, Confidence

*Corresponding author: Zeeshan Ahmed, Department of Community Medicine Dow University of Health Sciences, Karachi, Pakistan, Tel: +92-3232679255; E-mail: zeeshan.ahmed@duhs.edu.pk

Received February 03, 2014; Accepted March 25, 2014; Published March 29 2014

Citation: Ahmed Z, Zafar M, Khan AA, Anjum MU, Siddique MA (2014) Knowledge Attitude and Practices about Blood Donation among Undergraduate Medical Students in Karachi. J Infect Dis Ther 2: 134. doi:10.4172/2332-0877.1000134

Copyright: (C) 2014 Ahmed Z, et al. This is an open-access article distributed under the terms of the Creative Commons Attribution License, which permits unrestricted use, distribution, and reproduction in any medium, provided the original author and source are credited. 


\begin{tabular}{|c|c|}
\hline Characteristics & Frequency (Percentage) \\
\hline Age (years) mean (SD) & $20(1.3)$ \\
\hline Age & $248(41.4)$ \\
$17-20$ & $352(58.6)$ \\
$21-25$ & $181(30.2)$ \\
\hline Gender & $419(69.8)$ \\
Male & $300(50.0)$ \\
Female & $300(50.0)$ \\
\hline Class year $_{\text {Pre-clinical }}^{1}$ & $400(66.6)$ \\
Post-clinical $^{2}$ & $200(33.4)$ \\
\hline Medical college $^{2}$ & \\
\hline Public sector Medical college & $534(89.0)$ \\
Private sector Medical college & $66(11.0)$ \\
\hline Place of Residence \\
Karachi & \\
\hline Outside Karachi & \\
\hline
\end{tabular}

11\&2 year, ${ }^{2} 3-5$ years

Table 1: Socio demographic characteristic of undergraduate medical students of Karachi $(n=600)$

\begin{tabular}{|c|c|c|c|c|c|}
\hline Variables & $\begin{array}{c}\text { Appropriate } \\
\text { n (\%) } \\
553(92.2 \%)\end{array}$ & $\begin{array}{c}\text { Inappropriate } \\
\text { n (\%) } \\
47(7.8 \%)\end{array}$ & $\begin{array}{c}\text { COR } \\
(95 \% \mathrm{Cl})\end{array}$ & $\begin{array}{c}\text { AOR } \\
(95 \% \mathrm{Cl})\end{array}$ & P-Value \\
\hline $\begin{array}{c}\text { Age (years) } \\
17-20 \\
21-25\end{array}$ & $\begin{array}{l}234(42.3) \\
319(57.7)\end{array}$ & $\begin{array}{l}14(29.8) \\
33(70.2)\end{array}$ & $\begin{array}{c}0.6 \\
(0.3-1.0) \\
----\end{array}$ & & \\
\hline $\begin{array}{l}\text { Gender } \\
\text { Male } \\
\text { Female }\end{array}$ & $\begin{array}{l}162(29.3) \\
391(70.7)\end{array}$ & $\begin{array}{l}20(42.6) \\
27(57.4)\end{array}$ & $\begin{array}{c}1.8 \\
(1.0-3.3) \\
----\end{array}$ & $\begin{array}{c}2.0 \\
(1.1-3.8) \\
---\end{array}$ & 0.02 \\
\hline $\begin{array}{l}\text { Class Year } \\
\text { Pre-Clinical }^{2} \\
\text { Post-Clinical }^{3}\end{array}$ & $\begin{array}{l}279(50.5) \\
274(49.5)\end{array}$ & $\begin{array}{l}24(51.1) \\
23(48.9)\end{array}$ & $\begin{array}{c}1.0 \\
(0.6-1.9) \\
----\end{array}$ & & \\
\hline $\begin{array}{l}\text { Medical College } \\
\text { Public sector } \\
\text { Medical College } \\
\text { Private sector } \\
\text { Medical College }\end{array}$ & $\begin{array}{l}377(68.2) \\
176(31.8)\end{array}$ & $\begin{array}{l}23(48.9) \\
24(51.1)\end{array}$ & $\begin{array}{c}0.4 \\
(0.2-0.8) \\
----\end{array}$ & $\begin{array}{c}0.5 \\
(0.2-0.8) \\
----\end{array}$ & $<0.00$ \\
\hline $\begin{array}{c}\text { Place of Residence } \\
\text { Karachi } \\
\text { Outside Karachi }\end{array}$ & $\begin{array}{l}496(89.6) \\
57(10.4)\end{array}$ & $\begin{array}{l}39(83) \\
8(17)\end{array}$ & $\begin{array}{c}0.5 \\
(0.2-1.2) \\
----\end{array}$ & & \\
\hline
\end{tabular}

${ }^{1}$ Knowledge scale score $>9$ is appropriate while scores $\leq 9$ is inappropriate, ${ }^{21 \& 2}$ year, ${ }^{3} 3-5$ years

Table 2: Comparison of Knowledge level ${ }^{1}$ about blood donation by sociodemographic characteristics among study participants $(n=600)$

level (CI) 95\%, the sample size came out to be 585 students. A total 600 medical students from three medical colleges were selected by doing systematic sampling from each medical college.

\section{Sample selection}

Among 600 undergraduate medical students, 400 were required to be selected from public medical colleges, whereas 200 from a private medical college. Students were listed according to their roll numbers provided by medical institutes to form a sampling frame. Total numbers of students at two public medical colleges were 3000 and weighted sample was 400 therefore the $\mathrm{K}^{\text {th }}$ number was taken as eight. So, every $8^{\text {th }}$ student was selected in which half students was taken from preclinical years ( $1^{\text {st }}$ and $2^{\text {nd }}$ year) while half from the clinical years $\left(3^{\text {rd }}\right.$ to $5^{\text {th }}$ years). Similarly, for private medical college every $3^{\text {rd }}$ student was selected.

\section{Data collection procedure}

After approval from ethical review committee of Dow University of Health Sciences (DUHS), principal investigator and other team members of the project explained the nature and purpose of the study to all randomly selected students. Those, who agreed to participate, written informed consent was taken. Data was collected through face to face interviews during mid-semester period of one week at study area. A total of 600 undergraduate medical students were interviewed by the project team using a pre-tested, close-ended questionnaire to obtained basic information like age, gender, class year, medical college and place of residence whereas information regarding knowledge, attitude and practices of blood donation were also gathered through same questionnaire. If the randomly selected student didn't give the consent then we skipped that student and approached next student on the basis of random sampling according to Kth number. To avoid non response bias and making students easy to contribute, we designed the questionnaire that was not too long and didn't take too much time to complete.

\section{Data collection tool}

A structured questionnaire was required to be filled by project team. The questionnaire comprised of four major parts. Part one was designed to measure socio-demographic data for example age, gender, name of medical institute, class year and place of residence. Part two, three and four were about the knowledge, attitude and practices of undergraduate medical students regarding blood donation.

\section{Data analysis procedure}

The data was entered and analyzed by using Statistical package for Social Science (SPSS version 19) for windows. Descriptive statistics was used to determine mean and standard deviation for continuous variables like age while frequency and percentage for qualitative variables (gender, medical college, class year, place of residence etc). Scoring was done, for knowledge; each right response was given a score of 1 while a wrong or unsure response was scored 0 . Total knowledge scores can can be ranged between 0-15. Knowledge scores from 0 to 9 were considered as inappropriate knowledge while knowledge scores more than 9 was considered as having appropriate knowledge regarding blood donation. Attitude towards blood donation patients was assessed using a 8-item questionnaire where attitude scores between 0 to 5 were considered as negative attitude, and scores from 6 to 8 were considered as positive attitude. Practice was assessed using a questionnaire where total scores can range between 0-5. Practice score from 0-3 were considered as unwillingness to donate blood and score more than 3 were considered as willingness to donate blood. Multiple regressions were used to examine the effect of two or more independent variables on a single dependent variable to test the statistical significance at $95 \%$ confidence level. P-value of $<0.05$ was considered as significant.

\section{Results}

Table 1 showed social demographic characteristic of the study participants. A total of 600 interviews were performed during data collection period. The mean age of participants was $20 \pm 1.33$ years. Majority of respondents were females (69.8\%), having age 21-25 years (58.6\%), belonged to public sector medical college (66.6\%) and resident of Karachi (89.1\%). Distribution of participants in pre and clinical class year was equal; $50 \%$ in each group.

Table 2 showed knowledge scale of blood donation among study participants. All the participants were questioned to assess their knowledge about various aspects of blood donation and blood transfusion. The sum of responses was summarized as a knowledge score and a logistic regression analysis was done for age, gender, class year, medical colleges and place of residence. Majority of participants 


\begin{tabular}{|c|c|c|c|c|c|}
\hline Variables & $\begin{array}{c}\text { Positive Attitude n (\%) } \\
\text { 252(42.0) }\end{array}$ & $\begin{array}{c}\text { Negative Attitude } n(\%) \\
348(58.0)\end{array}$ & COR $(95 \% \mathrm{Cl})$ & AOR $(95 \% \mathrm{Cl})$ & P-Value \\
\hline $\begin{array}{c}\text { Age (years) } \\
17-20 \\
21-25\end{array}$ & $\begin{array}{l}97(38.5) \\
155(61.5)\end{array}$ & $\begin{array}{l}152(43.6) \\
196(56.4)\end{array}$ & $\begin{array}{c}1.2 \\
(0.9-1.7) \\
----\end{array}$ & & \\
\hline $\begin{array}{l}\text { Gender } \\
\text { Male } \\
\text { Female }\end{array}$ & $\begin{array}{l}63(25) \\
189(75)\end{array}$ & $\begin{array}{l}118(34) \\
230(66)\end{array}$ & $\begin{array}{c}1.5 \\
(1.1-2.2) \\
---\end{array}$ & $\begin{array}{c}1.5 \\
(1.1-2.2) \\
----\end{array}$ & 0.018 \\
\hline $\begin{array}{l}\text { Class year } \\
\text { Pre-Clinical }^{2} \\
\text { Post-Clinical }^{3}\end{array}$ & $\begin{array}{l}133(52.8) \\
119(47.2)\end{array}$ & $\begin{array}{l}169(48.5) \\
179(51.5)\end{array}$ & $\begin{array}{c}0.8 \\
(0.6-1.2) \\
---\end{array}$ & & \\
\hline $\begin{array}{l}\text { Medical College } \\
\text { Public sector Medical College } \\
\text { Private sector medical College }\end{array}$ & $\begin{array}{l}161(63.9) \\
91(36.1)\end{array}$ & $\begin{array}{l}238(68.4) \\
110(31.6)\end{array}$ & $\begin{array}{c}1.2 \\
(0.9-1.7) \\
---\end{array}$ & & \\
\hline $\begin{array}{c}\text { Place of Residence } \\
\text { Karachi } \\
\text { Outside Karachi }\end{array}$ & $\begin{array}{l}225(89.3) \\
27(10.7)\end{array}$ & $\begin{array}{l}311(89.3) \\
37(10.7)\end{array}$ & $\begin{array}{c}1.0 \\
(0.6-1.7) \\
----\end{array}$ & & \\
\hline
\end{tabular}

${ }^{1}$ Likert attitude scales cores $>5$ is positive attitude and score $\leq 5$ is negative attitudes, ${ }^{2} 1 \& 2$ year, ${ }^{3} 3-5$ years

Table 3: Comparison of characteristics on the basis of attitude Scale ${ }^{1}$ towards blood donation among study participants $(n=600)$

\begin{tabular}{|c|c|c|c|c|c|}
\hline Variables & $\begin{array}{c}\text { Willingness } \mathrm{n}(\%) \\
301(50.1)\end{array}$ & $\begin{array}{c}\text { Not-Willingness n (\%) } \\
299(49.9)\end{array}$ & COR $(95 \% \mathrm{CI})$ & AOR $(95 \% \mathrm{CI})$ & P-Value \\
\hline $\begin{array}{l}\text { Age } \\
17-20 \\
21-25\end{array}$ & $\begin{array}{l}125(41.5) \\
176(58.5)\end{array}$ & $\begin{array}{l}124(41.3) \\
175(58.5)\end{array}$ & $\begin{array}{c}1.1 \\
(0.7-1.4) \\
---\end{array}$ & & \\
\hline $\begin{array}{l}\text { Gender } \\
\text { Male } \\
\text { Female }\end{array}$ & $\begin{array}{l}78(26) \\
223(74)\end{array}$ & $\begin{array}{l}103(34.4) \\
196(65.6)\end{array}$ & $\begin{array}{c}1.5 \\
(1.0-2.1) \\
---\end{array}$ & $\begin{array}{c}1.5 \\
(1.0-2.1) \\
----\end{array}$ & 0.02 \\
\hline $\begin{array}{l}\text { Class Year } \\
\text { Pre-clinical }^{2} \\
\text { Post-Clinical }^{3}\end{array}$ & $\begin{array}{l}159(52.9) \\
142(47.1)\end{array}$ & $\begin{array}{l}142(47.5) \\
157(85.9)\end{array}$ & $\begin{array}{c}0.8 \\
(0.6-1.1) \\
---\end{array}$ & & \\
\hline $\begin{array}{l}\text { Medical College } \\
\text { Public sector medical College } \\
\text { Private sector Medical College }\end{array}$ & $\begin{array}{l}191(63.4) \\
110(36.6)\end{array}$ & $\begin{array}{l}209(69.9) \\
90(30.1)\end{array}$ & $\begin{array}{c}1.3 \\
(0.9-1.9) \\
---\end{array}$ & & \\
\hline $\begin{array}{l}\text { Place of Residence } \\
\text { Karachi } \\
\text { Outside Karachi }\end{array}$ & $\begin{array}{l}266(88.3) \\
35(11.7)\end{array}$ & $\begin{array}{c}270(90.3) \\
29(9.7)\end{array}$ & $\begin{array}{c}1.2 \\
(0.7-2.0) \\
---\end{array}$ & & \\
\hline
\end{tabular}

${ }^{1}$ The practice scale score $>3$ is Willingness to donate blood and score $\leq 3$ is Unwillingness. ${ }^{2} 1 \& 2$ year, ${ }^{3} 3-5$ years.

Table 4: Comparison of characteristics on the basis of practice scale ${ }^{1}$ for blood donation among study participants ( $\left.n=600\right)$

had appropriate knowledge regarding various aspect of blood donation (92.2\%). There was no statistically significant difference between age groups, class year and place of residence regarding blood donation. Male gender (AOR: 2.0, 95\% CI: 1.1-3.8) was associated with appropriate knowledge of blood donation when compared against female gender. Students of public sector medical colleges (AOR: 0.5, 95\% CI: 0.2-0.8) were less likely of having appropriate knowledge of blood donation when compared against students of private sector medical colleges.

Table 3 showed attitude scale of blood donation among study participants. All the participants were questioned to assess their attitude towards blood donation and blood transfusion. The sum of responses was summarized as an attitude score and a logistic regression analysis was done for age, gender, class year, medical colleges and place of residence. There were no statistically significant difference between age group, class year and place of residence regarding blood donation. However, male gender (AOR: 1.5, 95\% CI: 1.1-2.2) was associated with positive attitude towards blood donation when compared against female gender.

Table 4 showed practice scale of blood donation among study participants. All the participants were questioned to assess their willingness towards blood donation and blood transfusion. The sum of responses was summarized as a practice score and a logistic regression analysis was done for age, gender, class year, medical colleges and place of residence. There were no statistically significant difference between age group, class year, medical colleges and place of residence regarding blood donation. However, male gender (AOR: 1.5, 95\% CI: 1.0-2.1) was associated with willingness for blood donation when compared against female gender.

\section{Discussion}

This study was conducted in order to obtain information and inputs from undergraduate students of medical colleges which will be useful in implementing relevant donor recruitment strategies because this 
population can contribute to health promoting activities in the society. The hospital blood bank has two ways to meet this challenge, first to implement policies for appropriate use of blood [7] and second to increase healthy blood donor recruitment [8]. Blood donation decision making has been investigated worldwide for decades to understand the process better to increase donation efficiency [9-11].

This study among the medical graduates, who are a very potential and accessible source of voluntary non-remunerated and safe blood by the virtue of its collectability by coordinated blood transfusion services, revealed that, parental education seemed to have an overall impact on the knowledge regarding blood donation among the students [11,12].

Most of the students who were willing to donate blood, but they had not donated blood because of the lack of an opportunity to do so. This finding has been corroborated by the findings of past studies [12]. This showed that sufficient steps to involve students and to create opportunities for them to donate blood, is something that needs to be given due consideration, if we have to improve the voluntary collection of blood from them.

As compared to a previous study among college students, where there were a high number of respondents with a negative attitude towards blood donation [10], in our study, we found that equal number of both negative and positive attitude students about blood donation. Thus, the attitude of the students in our study was fifty percent positive attitude towards blood donation. This study also revealed that the unwillingness to donate blood was more among the female students and the major reasons were fear and perceived inconvenience which were associated with blood donation. This was also supported by the results of a past study [13].

This study suggests that there is sufficient basic knowledge regarding blood donation among undergraduate medical students. The score was also correlated to demographic characteristics within groups: younger individuals (18-40 years), males, residents of urban areas had significantly better scores than their counterparts. Many previous studies have shown that, compared to general population, university students have a higher level of knowledge and a more positive attitude towards blood donation [14-16].

It is a proven fact that voluntary non-remunerated blood donation is the safest and the most ideal way for improving the quality of blood which is collected through the blood banking services across the country. The youth from medical colleges, who are a very potential group of readily available donors, have to be encouraged to participate voluntarily in the blood donation activities. In a medical college hospital, they are very much accessible to the teaching hospitals as a part of their training program and this fact can be made use of, to include awareness sessions as a part of their regular training, right in the beginning of their course itself, so as to diffuse any doubts and misconceptions that the students may have regarding voluntary blood donation. Our study which found a lot of lack of information among the medical students validates the need for such early awareness program.

Major limitations of our study were those inherent to most studies on knowledge, attitudes and practices. Firstly, the responses were influenced by socially desirable attributes and there is the possibility of both recall bias and interviewer bias. Secondly, since Karachi is a multicultural city with a broad diversity of traditions, data from few medical colleges cannot be genelizable to other populations of country. Thirdly, data on those who did not agree to participate in the study were not collected and analyzed to exclude the possibility of a sampling bias.

\section{Conclusion}

In conclusion, the information received in this study highlights the need for appropriate health promotional campaigns for blood donation. Convenience of approach to the blood center and comfort during the process increase the chances of having a good donation experience and hence aid donor retention. Donor recruitment efforts should target groups less willing to donate and simultaneously seek to reinforce the positive behavior of willing groups converting previous donors into regular practice.

\section{Authors' Contributions}

$\mathrm{ZA}$ and $\mathrm{MZ}$ conceived the idea and designed the study in collaboration with AA and MU. MU, MA and ZA implemented the field study. AA, ZA and MZ coded the data and all authors contributed in the subsequent analysis. MU and MA participated in the design, data analysis and revising the manuscript. All authors read and approved the final manuscript.

\section{References}

1. Damesyn MA, Glynn SA, Schreiber GB, Ownby HE, Bethel J, et al. (2003) Behavioral and infectious disease risks in young blood donors: implications for recruitment. Transfusion 43: 1596-1603.

2. Zafar N (2000) A survey of blood transfusion practices. J Coll Physicians Surg Pak 10: 90-92.

3. Asif N, Kokhar N, llahi F (2004) Seroprevalence of HBV, HCV and HIV infection among voluntary non remunerated and replacement donors in Northern Pakistan. Pak J Med Sci 20: 24-28.

4. Zmijewski CM, Haesler WE (1982) Textbook of Blood Banking Science. Appleton-Century-Crofts, New York, USA - pp.258.

5. World Health Organization (WHO). Blood donation factsheet 2009.

6. Sabu KM, Remya A, Binu VS, Vivek R (2011) Knowledge, Attitude and Practice on Blood Donation among Health Science Students in a University campus, South India. Online J Health Allied Scs 10: 6.

7. Vos J (1998) Guidelines for appropriate prescribing of blood transfusions in Tanzania. Postgraduate Doctor 21: 77-80.

8. Gillespie TW, Hillyer CD (2002) Blood donors and factors impacting the blood donation decision. Transfus Med Rev 16: 115-130.

9. Allen J, Butler DD (1993) Assessing the effects of donor knowledge and perceived risk on intentions to donate blood. J Health Care Mark 13: 26-33.

10. Wiwanitkit $V(2000)$ A study on attitude towards blood donation among people in a rural district, Thailand. Southeast Asian J Trop Med Public Health 31: 609611.

11. Okpara RA (1989) Attitudes of Nigerians towards blood donation and blood transfusion. Trop Geogr Med 41: 89-93.

12. Gilani I, Kayani ZA, Atique M (2007) Knowledge, attitude and practices (kap) regarding blood donation prevalent in medical and paramedical personnel. Coll Physicians Surg Pak 17: 473-476.

13. Juárez-Ocaña S, Pizaña-Venegas JL, Farfán-Canto JM, Espinosa-Acevedo FJ, Fajardo-Gutiérrez A (2001) [Factors that influence non-donation of blood in relatives of patients at a pediatric hospital]. Gac Med Mex 137: 315-322.

14. Hosain GM, Anisuzzaman M, Begum A (1997) Knowledge and attitude towards voluntary blood donation among Dhaka University students in Bangladesh. East Afr Med J 74: 549-553.

15. Mwaba K, Keikelame MJ (1995) Blood donation behaviour and beliefs among a sample of high school students in Mmabatho. Curationis 18: 2-3.

16. Wiwanitkit $V(2002)$ Knowledge about blood donation among a sample of Tha university students. Vox Sang 83: 97-99.

Citation: Ahmed Z, Zafar M, Khan AA, Anjum MU, Siddique MA (2014) Knowledge, Attitude and Practices about Blood Donation among Undergraduate Medical Students in Karachi. J Infect Dis Ther 2: 134. doi:10.4172/2332 0877.1000134 